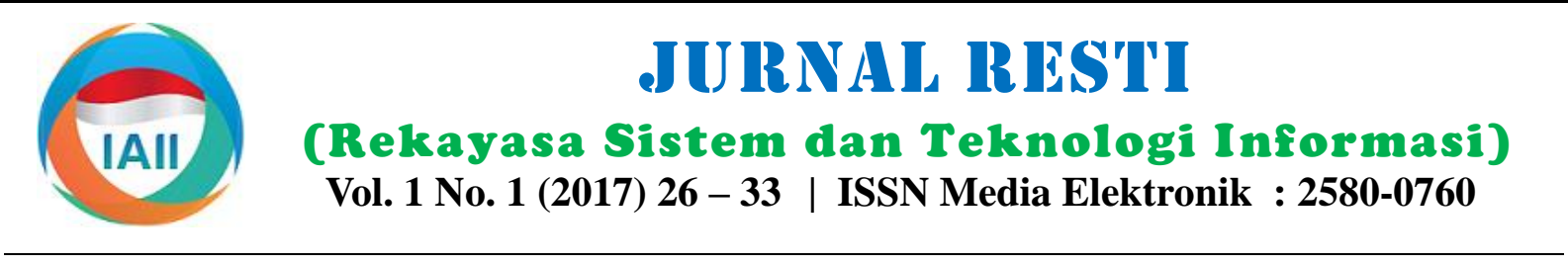

\title{
Sistem Informasi Kearsipan Tata Kelola Surat Pada Kantor Inspeksi BRI Kota Padang
}

\author{
Yanni Suherman \\ Manajemen Informatika, AMIK Jayanusa, suhermanyanni@yahoo.com
}

\begin{abstract}
A letter is a means to submit a statement or information in writing from one party to another. Such information may be notices, statements, requests, reports, thoughts, objections and so on. The management of letters within an institution is categorized into two, namely incoming and outgoing mail. The Inspection Office of BRI is representative of the directors of BRI in the regions that perform the supervisory function of the operational working units in the regions. In the mail archiving system, there are many piles of unorganized letters so when wants to check the incoming mail or outgoing mail that will be sent later. This system will be built using System Development Life Cycle (SDLC) which is better known as waterfall method. By applying this information system, the governance of this letter is facilitate the Inspection Office of BRI in the management of archiving of incoming and outgoing mail. Incoming and outgoing mail data will be stored into a database and applied to one of the object-oriented programming (OOP) languages making it easier to search mail data and each letter can be organized to be good.
\end{abstract}

Keywords: Mail, System, Archiving, Application, SDLC

\begin{abstract}
Abstrak
Surat adalah sarana untuk menyampaikan pernyataan atau informasi secara tertulis dari pihak yang satu kepada pihak yang lain. Informasi itu dapat berupa pemberitahuan, pernyataan, permintaan, laporan, pemikiran, sanggahan dan sebagainya. Pengelolaan surat dalam suatu lembaga diategorikan atas dua, yaitu surat masuk dan surat keluar. Kantor Inspeksi BRI merupakan perwakilan direksi BRI di daerah yang melaksanakan fungsi pengawasan terhadap unit kerja operasional di daerah. Dalam sistem pengarsipan surat, terjadi banyak tumpukan surat yang tidak terorganisir sehingga ketika ingin memeriksa surat masuk ataupun surat keluar yang akan dikirim nantinya. Sistem ini nantinya akan dibangun dengan menggunakan metode System Development Life Cycle (SDLC) yang lebih dikenal dengan istilah metode waterfall. Dengan mengaplikasikan sistem informasi tata kelola surat ini dapat memberikan kemudahan bagi Kantor Inspeksi BRI dalam pengelolaan pengarsipan surat masuk dan surat keluar. Data surat masuk dan surat keluar akan disimpan ke dalam suatu database dan diaplikasikan ke dalam salah satu bahasa pemrograman berorientasi objek (OOP) sehingga memudahkan dalam pencarian data surat dan setiap surat dapat terorganisir menjadi dengan baik.
\end{abstract}

Kata kunci: Surat, Sistem, Pengarsipan, Aplikasi, SDLC

(C) 2017Jurnal RESTI

\section{Pendahuluan}

Saat ini, teknologi di dunia khususnya dalam bidang bisnis selalu mengalami perkembangan bahkan setiap Pengelolaan surat memiliki perbedaan dalam tiap-tiap detiknya, informasi yang dibutuhkan pun semakin instansi. Sebuah instansi dalam pengelolaan surat ada beragam dan menarik, sehingga penggunaan komputer yang mengelola sesuai dengan bidangnya dalam artian akan memberikan kemudahan bagi pengguna dalam surat dikelola oleh bidang yang dituju oleh surat melakukan aktifitasnya untuk memperoleh informasi. tersebut. Institusi lain dalam melakukan pengelolaan Sistem informasi ataupun teknologi yang telah surat dilakukan pengurusan surat terpusat atau khusus diterapkan pada Kantor Inspeksi BRI Kota Padang saat karena dapat menghemat dan menghindari ini sudah sangat memadai, sehingga proses bisnis penduplikatan dalam penggunaan surat. Di dalam suatu berjalan dengan lancar khususnya dalam me- organisasi, pengelolaan surat masuk maupun surat 
keluar sangatlah diperlukan. Karena dengan puluhan surat, bahkan ratusan surat. Jumlah yang pengelolaan surat yang baik. Apabila suatu saat banyak tersebut jika tidak ditangani dengan baik organisasi tersebut membutuhkan kembali, surat tentunya akan dapat merugikan banyak pihak, tersebut akan mudah ditemukan

Surat adalah alat atau sarana komunikasi yang baik dalam bentuk tulisan maupun gambar yang digunakan oleh pihak-pihak terkait seperti perusahaan, organisasi, maupun pribadi kepada pihak lain untuk menyampaikan suatu informasi yang berfungsi sebagai bukti konkrit pada suatu hal atau kejadian tertentu.. Dalam suatu organisasi/perusahaan surat menurut prosedur pengurusannya dibagi menjadi dua yaitu surat masuk dan surat keluar.

Surat masuk merupakan komunikasi tertulis berupa semua jenis surat yang diterima dari perusahaan atau instansi lain kepada pihak penerima [1]. Surat masuk merupakan semua jenis surat yang diterima dari instansi lain maupun perorangan, baik yang diterima melalui pos maupun yang diterima melalui kurir dengan mempergunakan buku pengiriman/ekspedisi, sedangkan surat keluar adalah surat yang sudah lengkap (bertanggal, bernomor, berstempel, dan telah
ditanda tangani oleh pejabat yang berwenang) yang dibuat oleh suatu instansi, kantor atau lembaga untuk ditujukan atau dikirim kepada instansi, kantor atau lembaga lain. [2]

Prosedur pengelolaan surat masuk meliputi; perusahaan [4].

pengelompokan surat, membuka surat, pemerikasaan surat, pencatatan surat dan pendistribusian surat, sedangkan untuk surat keluar meliputi; pembuatan konsep, persetujuan konsep, pengertian surat, pemberian nomor, penyusunan surat, pengiriman surat. Prosedur pengolahan surat perlu diterapkan untuk masing-masing unit organisasi, karena merupakan sumber data atau informasi yang bermanfaat untuk kemajuan organisasi tersebut secara maksimal.

Sumber data atau informasi yang digunakan adalah surat. Namun demikian, ternyata masih terdapat kelemahan atau kekurangan terhadap proses bisnis intern pada Kantor Inspeksi BRI Padang yaitu dalam pengelolaan surat masuk dan surat keluar yang dikelola Arsip adalah setiap catatan atau record atau warkat pada bagian sekretariat yang nantinya surat-surat yang tertulis, tercetak atau ketikan dalam bentuk huruf, tersebut akan diberikan pada bagian supervisor. angka atau gambar, yang mempunyai arti dan tujuan Masalah yang sering dihadapi adalah banyaknya tertentu sebagai bahan komunikasi dan informasi yang tumpukan surat yang tidak terorganisir sehingga ketika terekam pada kertas, media komputer piringan dan supervisor ingin memeriksa surat masuk ataupun surat kertas fotocopy.

keluar yang akan dikirim nantinya tidak terkelola dengan baik

\section{Tinjauan Pustaka}

\subsection{Surat}

Surat berhubungan erat dengan kantor. Kantor tanpa surat berarti tidak ada aktivitas yang dapat dilakukan.

Setiap kantor dalam setiap harinya akan menangani Arsip mempunyai peran penting dalam proses

surat-surat. Dalam satu hari ada yang 1 surat, 2 surat, penyajian informasi bagi pimpinan yaitu untuk
Berdasarkan uraian di atas dapat didefinisikan bahwa arsip adalah naskah-naskah atau dokumen-dokumen sebagai pusat ingatan dari berbagai kegiatan atau organisasi dimana naskah-naskah tersebut disimpan sebaik mungkin secara sistematis ditempat yang telah disediakan agar lebih mudah dicari apabila diperlukan kembali [4]. 
membuat keputusan dan memusnahkan kebijakan- 2 kebijakan. Selain itu, peranan arsip adalah sebagai sumber dokumentasi dan dapat digunakan oleh pimpinan organisasi untuk mengambil keputusan secara tepat mengenai sesuatu masalah yang sedang dihadapi. Pada dasarnya pengelolaan arsip terdiri dari beberapa unsur pokok yaitu penciptaan arsip yang terdiri atas proses penciptaan arsip, penyimpanan, penemuan kembali, dan pemeliharaan arsip.

Pengelolaan itu digunakan sebagai proses mengkoordinir kegiatan-kegiatan secara efektif dan efisien dengan dan melalui orang lain. Berdasarkan Undang-undang Nomor 43 tahun 2009 pasal 40 ayat 2 (dua) pengelolaan sebuah arsip meliputi proses penciptaan, penggunaan dan pemeliharaan arsip serta penyusutan arsip. Pengelolaan sebuah arsip tersebut harus disesuaikan dengan nilai dan kegunaan arsip. Sebuah arsip tersebut harus dikelola dengan benar atau sesuai dengan proses supaya bermanfaat bagi pencipta, penerima dan pemakainya terutama apabila diperlukan maka arsip tersebut dapat ditemukan dengan waktu yang sesingkat mungkin.

Dengan semakin berkembangnya aktivitas suatu organisasi maka berkembang pula jumlah berkas yang ada dalam instansi tersebut. Perkembangan arsip akan sebanding dengan pertumbuhan jumlah pekerjaan tulis menulis yang terjadi di kantor dan sebanyak itu pula permasalahan yang ditimbulkan akibat kelahiran dokumen di tengah percaturan administrasi perkantoran. Arsip sudah tidak asing lagi bagi kalangan berorientasi objek gramming atau pemrogramann kantor, tetapi mengurus atau mengelola arsip berpikir serta berlogika dalam menghadapi masalahmerupakan pekerjaan yang tidak mudah. Manajemen masalah yang akan dicoba atasi dengan bantuan kearsipan akan membahas mengenai arsip mulai dari komputer OOP [7].

kelahiran sampai dengan kematian arsip [6].

Adapun jenis-jenis arsip yaitu terdiri dari :

\section{Ditinjau dari kepentingannya.}

a. Arsip tidak penting merupakan arsip arsip yang kegunaannya habis setelah dibaca. Contohnya seperti : surat undangan, memo.

b. Arsip biasa adalah arsip yang menmpunyai nilai kegunaan biasa untuk jangka waktu biasa. Contohnya : surat-surat niaga.

c. Arsip penting adalah arsip yang mempunyai nilai kegunaan besar untuk suatu organisasi dalam jangka waktu yang cukup lama. Contohnya : surat penjanjian kerjasama.

d. Arsip sangat penting adalah arsip yang mempunyai nilai guna sangat penting bagi suatu organisasi oleh karena itu arsip ini harus disimpan secara terus menerus atau abadi oleh organisasi tersebut. Contohnya : surat tanah, surat kepemilikan bangunan dan lain-lain.

e. Arsip rahasia adalah arsip yang hanya boleh diketahui oleh orang yang berkepentingan dengan surat tersebut. Contohnya : laporan keuangan, strategi pemasaran. a. Financial record adalah arsip yang berisi catatan yang berhubungan kegiatan atau masalah keuangan. Contoh : kwitansi, cek, giro, faktur dan lain-lain.

b. Personal record adalah arsip yang berisi tentang data-data kepegawaian. Contohnya : riwayat hidup, surat lamaran pekerjaan, absen pegawai dan lain-lain.

c. Inventory record adalah arsip yang berisi tentang data-data keadaan barang dagangan. Contoh : surat yang memuat tentang jumlah barang, kondisi barang, lokasi atau tempat barang tersebut.

d. Production Record adalah arsip yang berisi catatan mengenai keadaan produksi. Contohnya: laporan produksi.

e. Sales Record adalah arsip yang berisi catatansurat pesanan, list harga dan lain-lain.

\subsection{Object Oriented Programming (OOP)}

Pemrograman Berorientasi Objek atau Object Oriented Programming (OOP) adalah sebuah tata cara pembuatan program (programming paradigm) dengan menggunakan konsep objek yang memiliki data (atribut yang menjelaskan tentang objek) dan prosedur (function) yang dikenal dengan method.

\subsection{Database}

Database atau basis data adalah kumpulan (elementer) yang secara logika berkaitan dalam mempresentasikan fenomena atau fakta secara terstruktur dalam domain tertentu untuk mendukung aplikasi pada sistem tertentu [8].

Database merupakan kumpulan file yang saling berkaitan dan berinteraksi, relasi tersebut bila ditunjukan dengan kunci dari tiap-tiap file yang ada [9].

Dengan demikian berdasarkan dari beberapa pendapat tentang pengertian basis data, maka dapat disimpulkan bahwa basis data merupakan kumpulan beberapa file yang saling berelasi dan saling berkaitan untuk mendukung aplikasi pada sistem tertentu.

\section{Metodologi Penelitian}

Metode yang digunakan dalam merancang sistem informasi kearsipan ini adalah metode Sistem Development Life Cycle (SDLC). SDLC merupakan pola yang diambil untuk mengembangkan sistem perangkat lunak, yang terdiri dari tahap-tahap: catatan informasi mengenai penjualan . Contoh : 
perencanaan sistem (planning), analisa (analysis), desain (design), implementasi (implementation), pengujian (testing) dan pengelolaan (maintenance). Dalam rekayasa perangkat lunak, konsep SDLC mendasari berbagai jenis metodologi pengembangan perangkat lunak.

Metode SDLC dengan model proses air terjun (waterfall) atau lebih dikenal dengan istilah siklus kehidupan klasik. Air terjun, ciri khas dari air terjun adalah aliran searah dari atas ke bawah secara teratur. Begitu juga dengan model ini, setiap tahap dalam SDLC waterfall harus diselesaikan terlebih dahulu sebelum melanjutkan ke tahap berikutnya.

Gambar 1 berikut adalah bagan dari SDLC yang umum dimana terdiri atas 7 tahap. Berdasarkan tampilan gambar maka SDLC sering disebut metode 'Waterfall' karena lebih menyerupai air terjun.

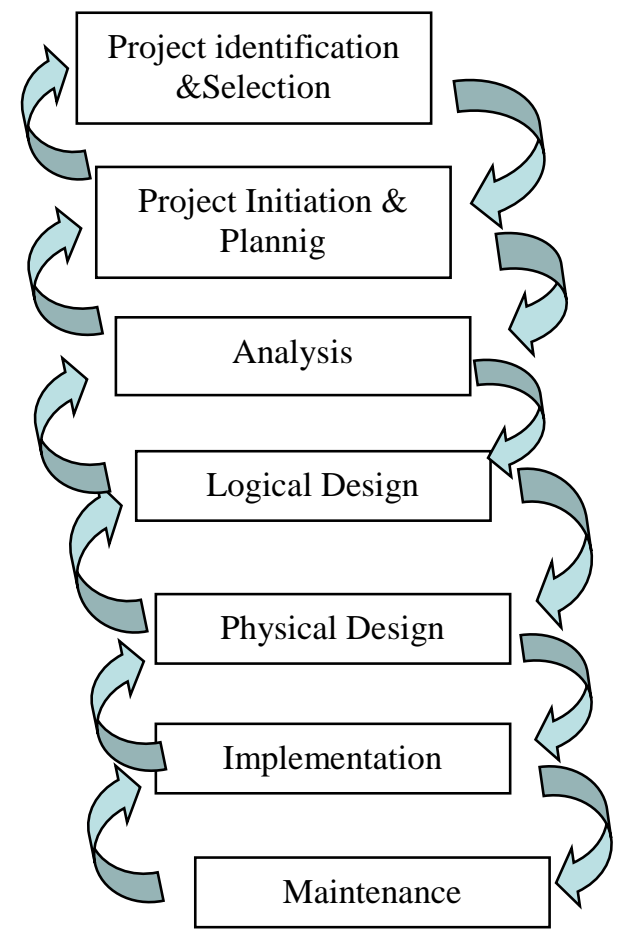

Gambar 1. Kerangka Kerja Penelitian

Output atau produk yang dihasilkan ditiap phase SDLC

a. Project Identification \& Selection, menghasilkan : Yang berhubungan dengan aktifitas perencanaan Sistem, yaitu menentukan prioritas sistem dan proyek, arsitektur dari data, jaringan, hardware, dan manajemen dari sistem informasi.

b. Project Initiation \& Planning, menghasilkan : Langkah terperinci atau rencana kerja untuk proyek, spesifikasi dari ruang lingkup sistem dan syarat/bentuk sistem (high-level), tugas untuk anggota tim dan sumber daya lainnya, sistem perundangan /pertimbangan sistem yang akan dibangun.

c. Analysis, menghasilkan : Penjabaran mengenai sistem yang ada termasuk masalah atau peluang yang ada yang direkomendasi untuk diperbaik/diatasi, ditingkatkan, atau mengganti sistem yang ada, uraian mengenai sistem pilihan dan sistem perundangan/pertimbangan untuk sistem yang terpilih, kesulitan yang ditemui dan menemukan berbagai solusi untuk mengatasi berbagai hambatan yang ditemukan.

d. Logical Design, menghasilkan : Berhubungan dengan fungsi-fungsi, spesifikasi terperinci dari semua element sistem (data, proses, input, output)

e. Physical design, menghasilkan : Lebih bersifat teknis, spesifikasi terperinci dari semua element sistem (program, file-file, sistem software, dll), rencana untuk teknologi baru.

f. Implementation, menghasilkan : Proses sistem, dokumentasi, prosedur pelatihan, dan support /dukungan yang dapat diberikan.

g. Maintenance, menghasilkan : Software versi terbaru atau dengan pembaruan untuk dokumentasi, pelatihan, support/dukungan

\section{Hasil dan Pembahasan}

Pada Kantor Inspeksi BRI Padang, terdapat beberapa masalah yang terjadi dalam mengelola surat masuk dan surat keluar. Pengolahan data pengarsipan surat masuk dan surat keluar yang sedang berjalan masih dilakukan secara manual, dimana surat masuk dan surat keluar tersebut masih dicatat pada buku besar. Hal tersebut mengkibatkan surat-surat tersebut menjadi tumpukan kertas dan mempersulit untuk mengetahui surat-surat apa saja yang masuk dan keluar pada pada Kanins tersebut.

Banyaknya tumpukan surat-surat yang diterima oleh sekretaris, sehingga sulitnya dalam mencari surat-surat yang ada jika dibutuhkan oleh supervisor ataupun inspektur. Selain itu, penggunaan komputer pun hanya sebatas untuk mengetik surat keluar yang diperintahkan oleh supervisor dan inspektur. Serta dalam pembuatan laporan surat masuk dan surat keluar masih menggunakan Microsoft Excel.

Secara detail, permasalahan yang ada dari sistem yang lama yaitu belum adanya sistem pengarsipan surat masuk dan surat keluar. Keuntungan dari sistem pengarsipan tersebut, secara umum yaitu mempermudah bagi sekretaris dalam mengelolah suratsurat yang masuk ataupun surat-surat yang keluar. Serta dalam pembuatan laporannya pun, tidak membutuhkan waktu yang lama.

Adapun perbaikan yang diusulkan sebelum proses pembuatan sistem adalah sebagai berikut: 
Perbaikan yang diusulkan antara lain:

1. Merancang sistem informasi pengarsipan surat masuk dan surat yang langsung terintegrasi ke database, sehingga pencarian data surat masuk dan j. surat keluar lebih mudah dan cepat.

2. Sistem yang diusulkan ini nantinya dilengkapi dengan penyimpanan arsip surat masuk dan surat keluar dalam bentuk image. Sehingga sekretaris tidak perlu kawatir lagi misalkan terjadinya kehilangan surat-surat yang masuk ataupun keluar.

3. Sistem yang akan dibangun berbasis client server, dimana sistem dapat di akses oleh supervisor sebagai client sedangkan server diletakkan pada bagian Sekretaris nantinya.

4. Sistem yang baru akan memudahkan bagi sekretaris untuk mencetak laporan-laporan yang dibutuhkan.

Setelah dilakukan analisis terhadap sistem yang akan diusulkan, maka dapat diuraikan dalam bentuk narasi sistem seperti berikut :

a. Instansi memberikan surat kepada Kanins, kemudian Kanins mencek surat yang datang dan menghasilkan surat yang telah dicek

b. Surat yang telah dicek diberikan kepada sekretaris, selanjutnya sekretaris meng-input surat masuk dan menghasilkan surat rahasia dan biasa yang masuk, selanjutnya diserahkan kepada inspektur

c. Inspektur memeriksa surat yang masuk dan menghasilkan surat rahasia dan biasa yang telah dipeiksa.

d. Selanjutnya, surat rahasia yang telah diperiksa diarsipkan oleh inspektur, sedangkan surat biasa yang telah diperiksa dibuatkan disposisi oleh inspektur yang menghasilkan surat biasa yang telah didisposisi.

e. Selanjutnya surat biasa yang telah didisposisi diserahkan kepada supervisor. Supervisor mencari surat biasa dan melakukan input disposisi surat yang mengghasilkan surat biasa dan lembar disposisi surat.

f. Surat biasa dan lembar disposisi surat diserahkan kepada bagian SAU untuk diberikan dan selanjutnya ditindaklanjuti.

g. Dari data surat masuk yang telah ada di database, bagian sekretaris mencetak laporan surat masuk keseluruhan yang menghasilkan laporan surat masuk prosedur-prosedur yang ada didalam sistem. CD pertanggal, perbulan, pertahun, jumlah surat biasa merupakan gambaran ruang lingkup sistem dan adanya perbulan dan jumlah surat rahasia perbulan kejelasan elemen yang termasuk di dalam atau di luar sebanyak dua rangkap setiap laporannya.

sistem. DFD merupakan alat bantu yang berbentuk

h. Selanjutnya laporan diserahkan kepada inspektur grafis yang sering digunakan dalam menganalisa dan untuk dicek dan ditandatangani menghasilkan merancang sistem, menggambarkan secara logika. Alat laporan yang telah ditandatangani.

Bantu ini juga mudah dimengerti oleh mereka yang

i. Untuk proses surat keluar, akan ada surat perintah kurang menguasai bidang komputer. ERD adalah suatu yang akan dikeluarkan oleh inspektur dan diagram yang menggambarkan hubungan diantara supervisor. Untuk surat rahasia, surat perintah dari entity-entity yang terdapat dalam suatu database. inspektur diberikan terlebih dahulu kepada Flowchart merupakan urutan langkah kerja suatu supervisor dan diteruskan ke bagian SAU untuk di proses untuk mencapai suatu tujuan dengan 
menggambarkannya dengan dalam bentuk simbolsimbol yang disusun secara sistematis.

ERD merupakan cara mengorganisasikan data dan digunakan untuk menggambarkan relasi antar tabel dengan tujuan untuk menjelaskan hubungan antar tabel penyimpanan.ERD menunjukan hubungan antar entity di dalam sistem, entity adalah suatu tempat, benda yang semuanya memiliki nama yang umum. Gambar 2 . merupakan salah satu contoh rancangan dengan menggunakan alat bantu perancangan sistem yaitu ERD.

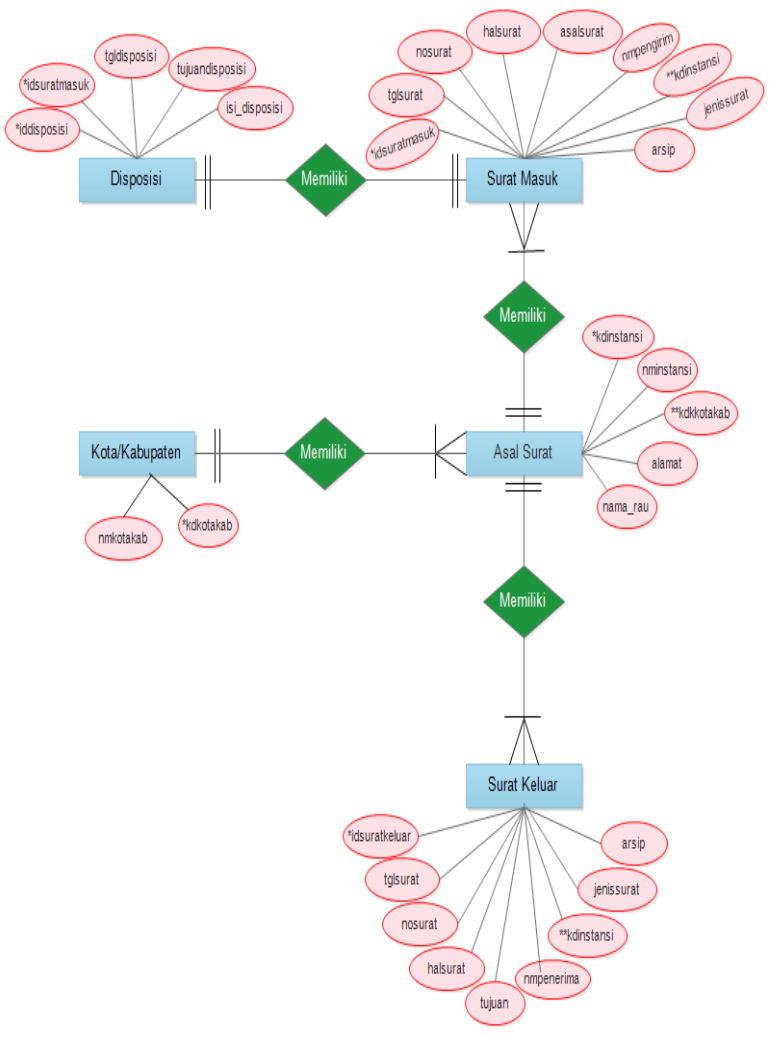

Gambar 2. Entity Relationship Diagram (ERD)

Pada database yang dibuat terdapat lima buah tabel utama, yaitu tabel kota/kabupaten, tabel asal surat, tabel surat masuk, tabel disposisi, dan tabel surat keluar.. Tabel 1. merupakan salah satu contoh rancangan tabel yang ada di sistem, yaitu rancangan tabel Surat Masuk.

Tabel 1. Disain Tabel Surat Masuk

\begin{tabular}{lllll}
\hline No & Field Name & Type & Size & Description \\
\hline 1 & idsrtmasuk* & Varchar & 30 & Id Surat Masuk \\
2 & Tglsurat & Date & - & Tanggal Surat \\
3 & Nosurat & Varchar & 50 & Nomor Surat \\
4 & Halsurat & Varchar & 100 & Hal \\
5 & Pengirim & Varchar & 100 & Tujuan Surat \\
6 & instansikd** & Varchar & 30 & ID Instansi \\
7 & jenissurat & Varchar & 30 & Jenis Surat \\
8 & Arsip & Text & & Hasil scan surat \\
\hline
\end{tabular}

Gambar 3. merupakan flowchart laporan surat yang masuk

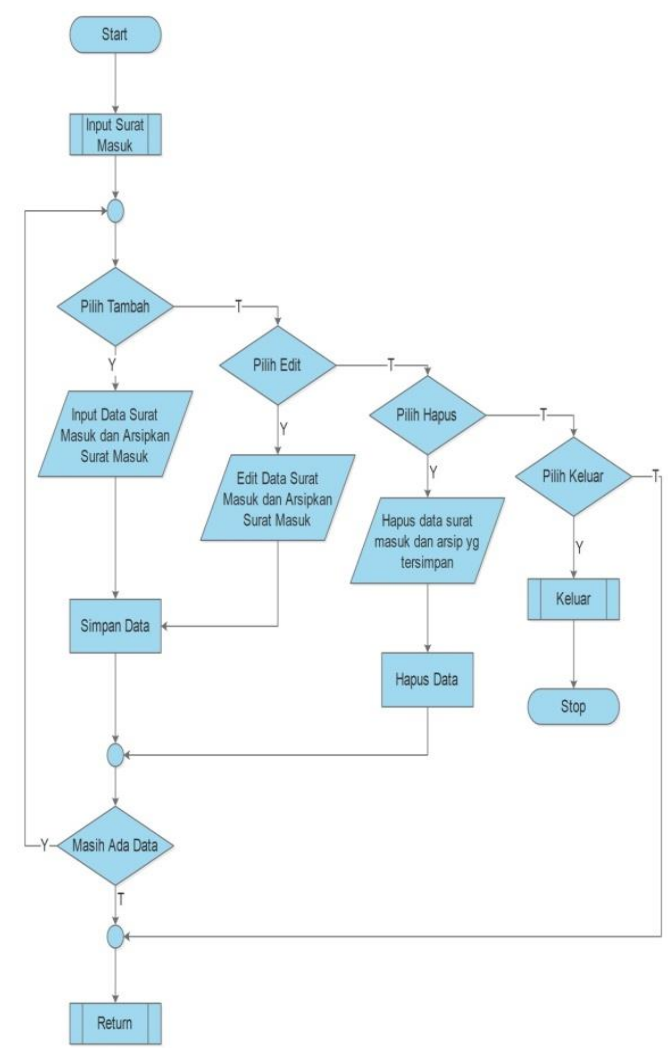

Gambar 3. Flowchart Laporan Surat masuk

Gambar 4. merupakan flowchart laporan surat yang keluar.

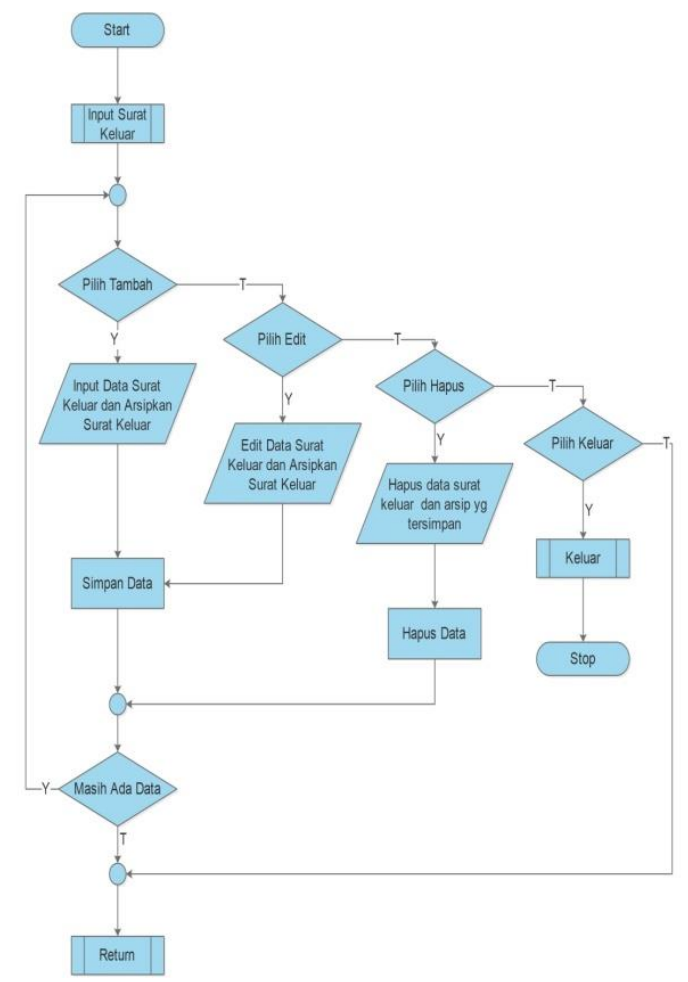

Gambar 4. Flowchart Laporan Surat masuk 
Setelah dilakukan perancangan dengan menggunakan Gambar 7. merupakan gambaran output berupa laporan alat bantu perancangan sistem selanjutnya disain yang dihasilkan dari sistem yang dibuat yaitu laporan tersebut dituangkan ke dalam sistem aplikasi dengan jumlah surat biasa yang keluar dalam periode bulan. menggunakan aplikasi vb.net. Adapun disain input dari sistem informasi tata kelola dan pengarsipan surat ini salah satu contohnya adalah disain input asal surat yang terlihat di dalam Gambar 5.

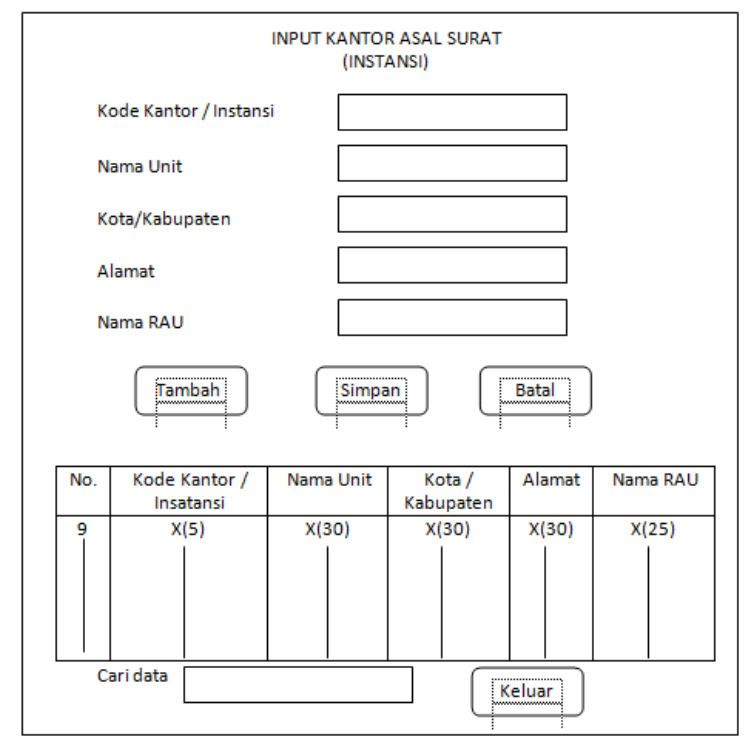

Gambar 5. Disain Input Asal Surat

Disain Output merupakan hasil rancangan atau gambaran output-output dari aliran sistem informasi yang baru, yang dapat berupa laporan-laporan yang diinginkan baik dalam bentuk informasi kelayar atau bentuk print (yang dicetak).

Gambar 6. merupakan gambaran output berupa laporan yang dihasilkan dari sistem yang dibuat yaitu laporan jumlah surat biasa yang keluar dalam periode bulan.

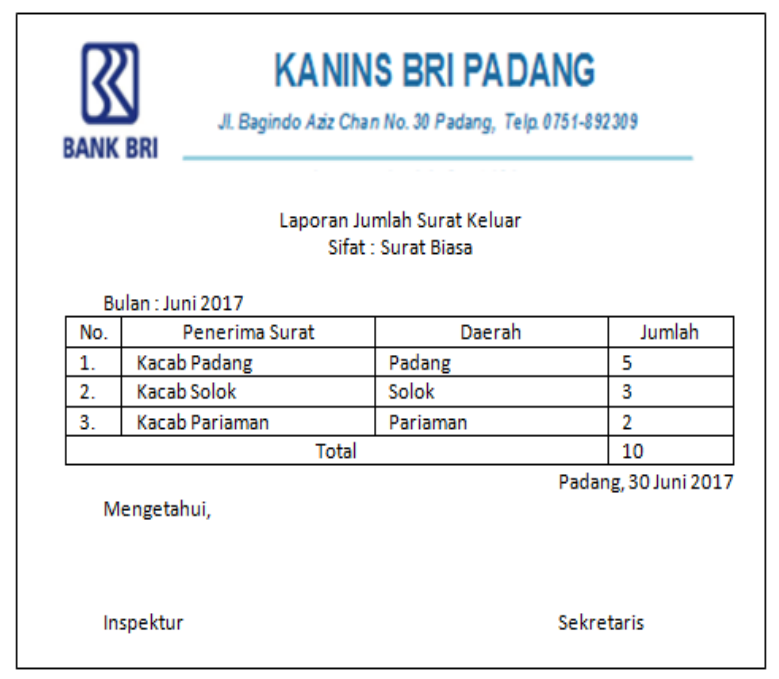

Gambar 6. Disain Laporan Jumlah Surat Keluar

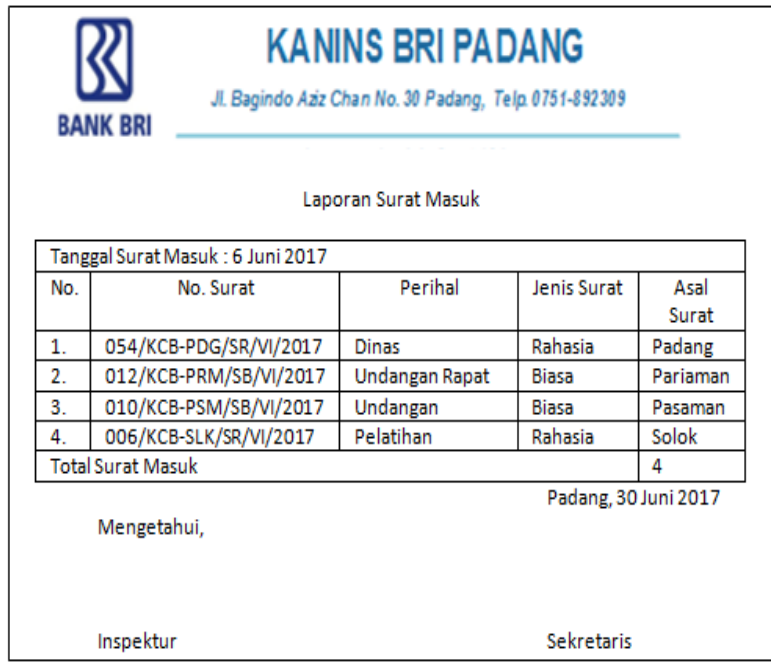

Gambar 7. Output Laporan Jumlah Surat Masuk

\section{Kesimpulan}

Dari penjelasan di atas maka dapat ditarik beberapa kesimpulan diantaranya adalah sebagai berikut :

\subsection{Simpulan}

1. Sistem aplikasi pengarsipan dapat mempermudah dalam pencarian data surat masuk dan surat keluar pada Kantor Inspeksi BRI Kota Padang.

2. Penerapan sistem basis data sebagai media penyimpanan data-data, akan mempermudah dalam pembuatan laporan-laporan yang dibutuhkan.

3. Dengan adanya sistem aplikasi pengarsipan dapat memberikan informasi yang cepat dan akurat bagi Kantor Inspeksi BRI Kota Padang sehingga dapat dijadikan sebagai bahan dalam pengambilan keputusan.

\subsection{Saran}

1. Perlu dilakukan pengembangan sistem yang lebih baik agar proses surat masuk dan surat keluar dapat terorganisir dengan baik

2. Pelaporan surat masuk dan surat keluar dilakukan secara bertahap agar pengecekan surat dan informasi yang didapat lebih maksimal.

\section{Daftar Rujukan}

[1] Syaban, R. M., 2015. Jurnal Algoritma Sekolah Tinggi Teknologi Garut. Pengembangan Sistem Informasi Pengelolaan Surat Masuk dan Surat Keluar Berbasis Web Di Dinas Sosial Tenaga Kerja Dan Transmigrasi Kabupaten Garut Menggunakan Framework PHP, 12, pp. 1-11. 
[2] Ermawaty, 2013. Pelangi Pendidikan. Pengelolaan Surat dan Tata Persuratan dalam Arsip, 20, pp. 83-88.

[3] Saputra, K. A., 2014. Indonesia Journal on Networking and Security. Perancangan Sistem Informasi Pengelolaan Surat Masuk dan Surat Keluar Pada MTs Guppi Jetiskidul, 3, pp. 59..

[4] Wuner, S. A., 2014. E-Journal Teknik Informastika, Analisa dan Perancangan Sistem Informasi Poliklinik Unsrat Berbasis Web, 14, pp. 1-5.

[5] Anwari,A., 2005. Jurnal Madani. Manajemen kearsipan dalam Penyelenggaraan Organisasi Publik, 2, pp. 28-31.

[6] Sasongko, J., 2009. Jurnal Teknologi Informasi DINAMIK. Rancang Bangun Sistem Informasi Manajemen Surat, 2, pp. 137145 .

[7] Nugroho, A., 2010. Rekayasa Perangkat Lunak Berbasis Objek dengan Metode USDP. Yogyakarta: Andi.

[8] Hariyanto, B., 2004. Sistem Manajemen Basis Data. Bandung: Informatika.

[9] Sovia, R., 2011. Jurnal PROCESSOR, Membangun Aplikasi ELibrary menggunakan Html, Php Script, dan Mysql Database, 6, pp. 38-54. 